\title{
Oil content, lipid profiling and oxidative stability of "Sefri" Moroccan pomegranate (Punica granatum L.) seed oil ${ }^{\text {h }}$
}

\author{
Ahmed Hajib $^{1}$, Issmail Nounah ${ }^{1}$, Hicham Harhar ${ }^{2}$, Said Gharby ${ }^{3, *}$, Badreddine Kartah ${ }^{1}$, \\ Bertrand Matthäus ${ }^{4}$, Khalid Bougrin ${ }^{1}$ and Zoubida Charrouf ${ }^{1}$ \\ ${ }^{1}$ Equipe de Chimie des Plantes et de Synthèse Organique et Bioorganique, URAC23, Faculty of Science, B.P. 1014, Geophysics, Natural \\ Patrimony and Green Chemistry (GEOPAC) Research Center, Mohammed V University, Rabat, Morocco \\ 2 Laboratory of Nanotechnology, Materials and Environment, Department of Chemistry, Faculty of Science, University Mohammed V, \\ Av. Ibn Batouta, BP. 1014, Rabat, Morocco \\ ${ }^{3}$ Laboratory Biotechnology, Materials and Environment (LBME), Faculty Polydisciplinary of Taroudant, University Ibn Zohr, Agadir, Morocco \\ ${ }^{4}$ Max Rubner-Institut, Federal Research Institute for Nutrition and Food, Working Group for Lipid Research, Schützenberg 12, D-32756 \\ Detmold, Germany
}

Received 6 October 2020 - Accepted 17 November 2020

\begin{abstract}
The aim of this study was to determine the chemical composition (fatty acids, tocopherols, and sterols) and evaluate the oxidative stability of Moroccan pomegranate (Punica granatum L.) seed oil. The oil content of pomegranate seed was $22.63 \mathrm{~g} / 100 \mathrm{~g}$ of dry weight. The fatty acid composition showed a dominance of conjugated linolenic acids (CLnAs) $(86.96 \mathrm{~g} / 100 \mathrm{~g})$. The most dominant fatty acid was punicic acid $(75.1 \mathrm{~g} / 100 \mathrm{~g})$, followed by catalpic acid $(6.7 \mathrm{~g} / 100 \mathrm{~g})$ and linoleic acid with amounts of $4.11 \mathrm{~g} / 100 \mathrm{~g}$. The seed oil only contained a low level of saturated fatty acids with palmitic $(2.64 \mathrm{~g} / 100 \mathrm{~g})$ and stearic acids $(1.73 \mathrm{~g} / 100 \mathrm{~g})$ as main saturated fatty acids. The sterol marker, $\beta$-sitosterol, accounted for $404.59 \mathrm{mg} / 100 \mathrm{~g}$ of the total sterol content in the seed oil. Total tocopherol content in seed oil was $332.44 \mathrm{mg} / 100 \mathrm{~g}$. $\gamma$-tocopherol $(190.47 \mathrm{mg} / 100 \mathrm{~g}$ oil) is the major constituent, followed by $\alpha$-tocopherol $(74.62 \mathrm{mg} / 100 \mathrm{~g}$ oil) and $\delta$-tocopherol $(53.3 \mathrm{mg} / 100 \mathrm{~g}$ oil). The induction time calculated by the Rancimat accelerated method was found to be of $3.6 \mathrm{~h}$ at $120^{\circ} \mathrm{C}$. In terms of oil, pomegranate seed oil may be considered as a valuable source for new multipurpose products with industrial, cosmetic and pharmaceutical uses.
\end{abstract}

Keywords: Fatty acids / oxidation / Punica granatum L. / seed oil / sterols / tocopherols

Résumé - Teneur en huile, profil lipidique et stabilité oxydative de l'huile végétale du grenadier marocain "Sefri" (Punica granatum L.). Cette étude a pour but de déterminer la composition en acides gras, tocophérols et stérols, et d'évaluer la stabilité oxydative de l'huile végétale du grenadier marocain (Punica granatum L.). Nos résultats montrent que la teneur en huile est de $22,63 \mathrm{~g} / 100 \mathrm{~g}$ de graines sèches. L'analyse de la composition en acides gras a montré une dominance des acides linoléniques conjugués $(86,96 \mathrm{~g} / 100 \mathrm{~g})$. En effet, l'acide gras le plus dominant était l'acide punicique $(75,1 \mathrm{~g} / 100 \mathrm{~g})$, suivi de l'acide catalpique $(6,7 \mathrm{~g} / 100 \mathrm{~g})$ et de l'acide linoléique $(4,11 \mathrm{~g} / 100 \mathrm{~g})$. Cependant, l'huile du grenadier contient une faible teneur en acides gras saturés (acides palmitique $(2,64 \mathrm{~g} / 100 \mathrm{~g})$ et stéarique $(1,73 \mathrm{~g} / 100 \mathrm{~g})$. L'analyse de la composition en stérols a montré une dominance du $\beta$-sitostérol $(404,59 \mathrm{mg} / 100 \mathrm{~g}$ d'huile). Également, la teneur totale en tocophérol était de 332,44 mg/100g d'huile, avec le $\gamma$-tocophérol (190,47 mg/100g d'huile) comme composé majoritaire, suivi de l' $\alpha$-tocophérol $(74,62 \mathrm{mg} / 100 \mathrm{~g}$ d'huile) et du $\delta$-tocophérol $(53,3 \mathrm{mg} / 100 \mathrm{~g}$ d'huile). Du point de vue stabilité oxydative, le temps d'induction calculé par la méthode accélérée Rancimat est de $3,6 \mathrm{~h}$ à $120^{\circ} \mathrm{C}$. En termes d'huile, les graines du grenadier peuvent être considérées comme une source précieuse pour de nouveaux produits à usage industriel, cosmétique et pharmaceutique.

Mots clés : Acides gras / huile des graines / oxydation / Punica granatum L. / stérols / tocophérols

\footnotetext{
it Contribution to the Topical Issue "Minor oils from atypical plant sources / Huiles mineures de sources végétales atypiques".

*Correspondence: s.gharby@yahoo.fr; s.gharby@uiz.ac.ma
} 


\section{Introduction}

Pomegranate (Punica granatum L., Punicaceae) is an ancient, beloved plant and delicious fruit consumed worldwide (Jing et al., 2012). They are widely grown in the Mediterranean regions and India, but sparsely cultivated in the USA, China, Japan and Russia (Fadavi et al., 2006). The edible parts of pomegranate fruits are consumed fresh and they are also used for the preparation of fresh juice (Fadavi et al., 2006). The fruits contain considerable amounts of seeds $(40-100 \mathrm{~g} / \mathrm{kg}$ fruit weight) (Syed et al., 2007), that are usually waste products from the fruit processing. Pomegranate seeds a rich source of lipids, which approximately 12 to $20 \%$ of total seeds weight, varies according to cultivars (Ky`ralan et al., 2009). Many studies have indicated the pharmaceutical importance of pomegranate seed oil (PSO). For instance, they have been reported to promote epidermal tissue regeneration, boost the immune system in vivo, reduce the accumulation of hepatic triglycerides and display chemopreventive activity against hormone-related (prostate and breast) and colon cancers (Melo et al., 2014).

Pomegranate seed oil (PSO) contains predominantly unsaturated fatty acids including oleic, linoleic and in particular, high levels of conjugated linolenic acids (CLnAs), also known as trienoic acids (Lansky and Newman, 2007; Vroegrijk et al., 2011; Melo et al., 2014). The specific trienoic fatty acid found in pomegranate seed oil is referred to as punicic acid, which is a polyunsaturated fatty acid (18:3n-5), also called trichosanic acid, cis 9, trans 11, cis 13. Punicic acid is referred as a "super CLnA" whose effect is even more potent than that of an ordinary CLnA (Melo et al., 2014; Aruna et al., 2016). It possesses a wide array of biological properties including antidiabetic (Arao et al., 2004a; Arao et al., 2004b), anti-inflammatory (Boussetta et al., 2009), hypolipidemic (Koba et al., 2007a), and anticarcinogenic activity against various forms of cancer (Tsuzuki et al., 2004).

Currently, pomegranate plant is produced throughout the world in tropical and sub-tropical areas. The Mediterranean countries, India, Iran and Californian are considered as the main producers. Argentina, Brazil, Peru, Chile and South Africa are the other important producer countries (Kahramanoglu and Usanmaz, 2016). In 2014, the total production of pomegranate in the world was estimated to be around three million tons. Morocco is one of the biggest producers, the cultivation of pomegranate covers an area of about 4000 ha which gives an estimated production of $46000 \mathrm{~T}$, an average yield of $12 \mathrm{~T} / \mathrm{ha}$ (Haddioui, 2012).

Many studies indicate a quantitative and qualitative difference in the chemical composition of pomegranate species oil, growing in different regions. To our knowledge, no study has been done to analyse Moroccan pomegranate seed oil. The aim of this study is to determine the lipid profile and evaluate the oxidative stability of the pomegranate seed oil growing in Morocco.

\section{Material and methods}

\subsection{Sample collection}

Pomegranate seeds and press oil samples, from "Sefri" Moroccan variety, analysed to determine the chemical composition and oxidative stability, were collected and prepared in 2017 from Flora cooperative (Boujad city, Morocco, 32 $\left.46^{\prime} 10^{\prime \prime} \mathrm{N} 6^{\circ} 23^{\prime} 49^{\prime \prime} \mathrm{W}\right)$. The annual average temperature in this region was $29^{\circ} \mathrm{C}$, while the annual average precipitation recorded between October and April was $1 \mathrm{~mm}$.

\subsection{Reagents}

Petroleum ether $\left(40-60^{\circ}\right)$ was of analytical grade ( $>98 \%$; Merck, Darmstadt, Germany). Heptane and tert-butyl methyl ether were of HPLC grade (Merck, Darmstadt, Germany). Tocopherol and tocotrienol standard compounds were purchased from Cal Biochem (Darm-stadt, Germany). Sterol standard compounds were obtained from Aldrich (Munich, Germany).

\subsection{Oil content}

The oil content was determined according to the method ISO standard (ISO 659, 1998). About $2 \mathrm{~g}$ of the seeds were ground in a ball mill and extracted with petroleum ether in a Twisselmann apparatus for $6 \mathrm{~h}$. The solvent was removed by a rotary evaporator at $40^{\circ} \mathrm{C}$ and 25 Torr. The oil was dried by a stream of nitrogen and stored at $-20^{\circ} \mathrm{C}$ until used.

\subsection{Fatty acid composition}

The fatty acid composition was determined following the ISO standard (ISO 12966-2, 2017). Fatty acids (FAs) were converted into fatty acid methyl esters (FAMEs) by shaking a solution of $60 \mathrm{mg}$ oil and $3 \mathrm{~mL}$ of hexane with $0.3 \mathrm{~mL}$ of $2 \mathrm{~N}$ methanolic potassium hydroxide for $25 \mathrm{~min}$. The fatty acid composition was determined as their corresponding methyl esters by gas chromatography (Varian 5890) coupled with a flame ionization detector (GC-FID). The capillary column CPSil 88 (100 m long, $0.25 \mathrm{~mm}$ ID, film thickness $0.2 \mu \mathrm{m}$ ) was used. The carrier gas was helium and the total gas flow rate was $1 \mathrm{~mL} / \mathrm{min}$. The temperature program was as follows: from $155^{\circ} \mathrm{C}$; heated to $220^{\circ} \mathrm{C}\left(1.5^{\circ} \mathrm{C} / \mathrm{min}\right), 10 \mathrm{~min}$ isotherm; injector $250^{\circ} \mathrm{C}$, detector $250^{\circ} \mathrm{C}$; carrier gas $36 \mathrm{~cm} / \mathrm{s}$ hydrogen; split ratio 1:50; detector gas $30 \mathrm{~mL} / \mathrm{min}$ hydrogen; $300 \mathrm{~mL} / \mathrm{min}$ air and $30 \mathrm{~mL} / \mathrm{min}$ nitrogen; manual injection volume less than $1 \mu \mathrm{l}$. The peak areas were computed by the integration software, and percentages of fatty acid methyl esters (FAME) were obtained as weight percentage by direct internal normalization method.

\subsection{Tocopherol composition}

For determination of tocopherols, a solution of $250 \mathrm{mg}$ of press oil in $25 \mathrm{~mL}$ of n-heptane was directly used for the HPLC as descripted in Hajib et al., (2018) work. The HPLC analysis was conducted using a Merck-Hitachi low-pressure gradient system, fitted with a L-6000 pump, a Merck-Hitachi F-1000 fluorescence spectrophotometer (detector wavelengths for excitation $295 \mathrm{~nm}$, for emission $330 \mathrm{~nm}$ ), and a D-2500 integration system. The samples in the amount of $20 \mu$ l were injected by a Merck 655-A40 autosampler onto a Diol phase HPLC column $25 \mathrm{~cm} \times 4.6 \mathrm{~mm}$ ID (Merck, Darmstadt, 
Table 1. Comparison of oil yield (g/100g) of "Sefri” Moroccan pomegranate seed oil with literature.

\begin{tabular}{llllll}
\hline $\begin{array}{l}\text { Pomegranate } \\
\text { Morocco } \\
\text { (our study) }\end{array}$ & $\begin{array}{l}\text { Turkey } \\
\text { (Ky`ralan et al., 2009) }\end{array}$ & $\begin{array}{l}\text { Tunisia } \\
\text { (Elfalleh et al., 2011) }\end{array}$ & $\begin{array}{l}\text { China } \\
\text { (Jing et al., 2012) }\end{array}$ & $\begin{array}{l}\text { Spain } \\
\text { (Fernandes et al., 2015) }\end{array}$ & $\begin{array}{l}\text { Iran } \\
\text { (Fadavi et al., 2006) }\end{array}$ \\
\hline Oil content & $22.63 \pm 0.54$ & $13.95-24.13$ & $5.89-21.58$ & $11.4-14.9$ & $4.44-13.7$ \\
\hline
\end{tabular}

Values are given as means of three replicates \pm SD.

Germany) used with a flow rate of $1.3 \mathrm{~mL} / \mathrm{min}$. The mobile phase used was n-heptane/tert-butyl methyl ether $(99: 1, \mathrm{v} / \mathrm{v})$.

\subsection{Sterol composition}

The sterol composition of the press oil was determined following the ISO standard (ISO 12228-1, 2014). In brief, $250 \mathrm{mg}$ of press oil was saponified with a solution of ethanolic potassium hydroxide $(2 \mathrm{~N})$ by boiling under reflux. The unsaponifiable matter was isolated by solid-phase extraction on an aluminum oxide column (Merck, Darmstadt, Germany) on which fatty acid anions were retained and sterols passed through. The sterol fraction was separated from unsaponifiable matter by thin-layer chromatography (Merck, Darmstadt, Germany), re-extracted from the TLC material, and afterward, the composition of the sterol fraction was determined by GLC using betulin as internal standard. The compounds were separated on a SE 54 CB (Macherey-Nagel, Düren, Germany; $50 \mathrm{~m}$ long, $0.32 \mathrm{~mm}$ ID, $0.25 \mu \mathrm{m}$ film thickness). Further parameters were as follows: helium $(1 \mathrm{~mL} / \mathrm{min})$ as a carrier gas, split ratio 1:20, injection and detection temperature adjusted to $320^{\circ} \mathrm{C}$, temperature program, $245^{\circ} \mathrm{C}$ to $260^{\circ} \mathrm{C}$ at $5^{\circ} \mathrm{C} / \mathrm{min}$. Peaks were identified either by standard compounds ( $\beta$-sitosterol, campesterol, stigmasterol) by a mixture of sterols isolated from rapeseed oil (brassicasterol) or by a mixture of sterols isolated from sunflower oil $(\Delta-7$-avenasterol, $\Delta$-7-stigmasterol, and $\Delta$-7-campesterol). All other sterols were identified by GC-MS for the first time and afterwards by comparison of the retention time.

\subsection{Oxidative stability}

The oxidative stability of the press oil was determined by the Rancimat method, according to Gharby et al., (2012) work. All experiments were carried out with a 743 Rancimat (Methrom AG, Herisau, Switzerland). In brief, $3.6 \mathrm{~g}$ press oil were weighed into the reaction vessel, which was placed into the heating block kept at $120^{\circ} \mathrm{C}$. Air flow was set at $20 \mathrm{~L} / \mathrm{h}$ for all determinations. Volatile compounds released during the degradation process were collected in a receiving flask filled with $60 \mathrm{~mL}$ of distilled water. The conductivity of this solution was measured and recorded. The resulting curves were evaluated automatically by the software of the Rancimat. All determinations were carried out in triplicate.

\section{Results and discussion}

\subsection{Oil content}

The oil content of pomegranate seed oil from Morocco was $22.63 \pm 0.54 \mathrm{~g} / 100 \mathrm{~g}$ (Tab. 1), which is comparable with that from
Turkey (13.95-24.13 g/100g) and Tunisia (5.89-21.58 g/100g), as reported by Ky`ralan et al., (2009) and Elfalleh et al., (2011), respectively. Jing et al., (2012) found less oil in the pomegranate seeds from China (11.4-14.9 g/100g). The Pomegranate seeds investigated by Fernandes et al., (2015) (from Spain) and Fadavi et al., (2006) (from Iran) also contained lower amounts (4.44-13.7 g/100g and 6.63-19.3 g/100g, respectively) of oil. According to Taoufik et al., (2015), this variation can be due to the extraction method, cultivars, climatic factors and environmental conditions.

\subsection{Fatty acid composition}

The fatty acid profiles of cold pressed pomegranate (Punica granatum L.) seed oil determined by GC are shown in Table 2. The saturated fatty acid (SFA) represented only $4.74 \mathrm{~g} / 100 \mathrm{~g}$, palmitic acid (C16:0) was the predominant SFA with $2.64 \mathrm{~g} / 100 \mathrm{~g}$ followed by stearic acid (C18:0) $1.73 \mathrm{~g} / 100 \mathrm{~g}$ and arachidic acid (C20:0) $0.37 \mathrm{~g} / 100 \mathrm{~g}$. The content of UFA was $95.13 \mathrm{~g} / 100 \mathrm{~g}$, in which only $4.06 \mathrm{~g} / 100 \mathrm{~g}$ was monounsaturated fatty acids (MUFA) and $91.07 \mathrm{~g} / 100 \mathrm{~g}$ was PUFA. Major PUFA was punicic acid (C18:3 (c9, t11, c13)) which accounted for $75.1 \mathrm{~g} / 100 \mathrm{~g}$, followed by catalpic acid (C18:3 (t9, $\mathrm{t} 11$, c13) $(6.7 \mathrm{~g} / 100 \mathrm{~g})$ and linoleic acid (C18:2) with amounts of $4.11 \mathrm{~g} / 100 \mathrm{~g}$. Four conjugated linolenic acids (CLnA) were identified, as different geometric isomers of conjugated linolenic acid, namely punicic acid (C18:3 (c9, t11, c13)), which is the major isomer $(75.1 \mathrm{~g} / 100 \mathrm{~g})$, followed by catalpic acid (C18:3 (t9, t11, c13)) (6.7 g/100g), $\alpha$-eleostearic acid (C18:3 (c9, t11, t13)) (3.73 g/100g), and $\beta$-eleostearic acid (C18:3 (t9, t11, t13)) (1.43 g/100g). PSO fatty acid composition was found to be in the range of previously published values for pomegranate seed oil from other countries reported in the literature (Fadavi et al., 2006; Sassano et al., 2009; Elfalleh et al., 2011; Hernandez et al., 2011; Jing et al., 2012).

Punicic acid was first isolated from pomegranate seed oil by Toyama and Tsuchiya, (1935). This fact was later confirmed by a reinvestigation of the oil by Farmer and Van den Heuvel (1936) and also by other authors (Ahlers et al., 1954). According to Sassano et al., (2009) in nature, CLnAs are not found to any great extent in animal fat, but they are found in many seed oils as either $\mathrm{C} 18$ trienes or $\mathrm{C} 18$ tetraenes. The most commonly CLnAs known isomers found in seed oils from important plants are $\alpha$-eleostearic acid (Vernicia fordii), punicic acid (Punica granatum L.), calendic acid (Calendula officinalis L.), jacaric acid (Jacaranda mimosifolia), catalpic acid (Catalpa ovata), $\beta$-calendic (Calendula officinalis L.) and $\alpha$-parinaric acid (Parinarium laurinum) (Sassano et al., 2009; Melo et al., 2014). In general, CLnAs are synthesized from linoleic acid through a specific conjugase enzyme, but they 
Table 2. Comparison of fatty acid composition (g/100g) of "Sefri" Moroccan pomegranate seed oil with literature.

\begin{tabular}{|c|c|c|c|c|c|c|}
\hline Compound & $\begin{array}{l}\text { Our results } \\
\text { (g/100g oil) }\end{array}$ & (Jing et al., 2012) & $\begin{array}{l}\text { (Fadavi et al., } \\
\text { 2006) }\end{array}$ & $\begin{array}{l}\text { (Sassano } \\
\text { et al., 2009) }\end{array}$ & $\begin{array}{l}\text { (Hernandez } \\
\text { et al., 2011) }\end{array}$ & $\begin{array}{l}\text { (Elfalleh } \\
\text { et al., 2011) }\end{array}$ \\
\hline Miristic acid (C14:0) & - & - & $0.1-4.7$ & - & - & $\operatorname{Tr}-0.85$ \\
\hline Stearic acid (C18:0) & $1.73 \pm 0.17$ & $1.6-2.81$ & $0.3-9.9$ & $2.21-2.37$ & $1.6-2.38$ & $2.28-15.64$ \\
\hline Oleic acid (C18:1) & $3.64 \pm 0.29$ & $3.37-6.01$ & $4.8-17.4$ & $6.82-7.17$ & $5.23-6.85$ & $3.03-12.88$ \\
\hline Arachidic acid (C20:0) & $0.37 \pm 0.09$ & $0.25-0.35$ & - & $0.43-0.49$ & - & $\operatorname{Tr}-1.7$ \\
\hline Gadoleic acid (C20:1) & - & - & - & - & - & $0.6-9.94$ \\
\hline Ecosoneic acid (C20:1) & $0.42 \pm 0.11$ & & - & $0.64-0.66$ & - & - \\
\hline Behenic acid (C22:0) & - & - & $0-3.9$ & - & - & - \\
\hline Punicic acid (C18:3) & $75.1 \pm 1.62$ & $73.45-78.80$ & $55.8-86.6$ & $64.9-71.76$ & $80.41-91.03$ & $12.45-55.45$ \\
\hline Nervonic acid (C24:1) & - & - & - & $0.15-0.24$ & - & - \\
\hline SFA & 4.74 & & & & & \\
\hline MUFA & 4.06 & & & & & \\
\hline PUFA & 91.07 & & & & & \\
\hline UFA & 95.13 & & & & & \\
\hline CLnA & 86.96 & & & & & \\
\hline Total & 99.87 & & & & & \\
\hline
\end{tabular}

Values are given as means of three replicates $\pm \mathrm{SD}$.

Table 3. Comparison of sterol composition (mg/100g) of "Sefri" Moroccan pomegranate seed oil with literature.

\begin{tabular}{lccc}
\hline Compound & Our results $(\mathrm{mg} / 100 \mathrm{~g})$ & (Fernandes et al., 2015) & (Pande and Akoh, 2009) \\
\hline Cholesterol & $0.39 \pm 0.01$ & - & - \\
Brassicasterol & - & - & $0-2.2$ \\
Campesterol & $38.18 \pm 1.91$ & $25.1-36.3$ & $17.9-39.3$ \\
Stigmasterol & $15.53 \pm 1.28$ & $11.8-17.0$ & $27.8-46.3$ \\
$\beta$-Sitosterol & $404.59 \pm 4.72$ & $220.1-354.2$ & $243.5-338.3$ \\
$\Delta$-5-Avenasterol & $17.86 \pm 0.29$ & - & - \\
$\Delta$-7-Stigmasterol & $2.67 \pm 0.17$ & - & - \\
Sitostanol & - & $14.8-25.9$ & - \\
$\Delta$-7-Avenasterol & $0.76 \pm 0.08$ & - & - \\
Others & - & $89.8-122.3$ & - \\
\hline
\end{tabular}

Values are given as means of three replicates $\pm \mathrm{SD}$.

may also be produced during the processing of vegetable oils, as a result of isomerization and dehydration of secondary oxidation products of linoleic and $\alpha$-linolenic acids (Koba et al., 2007b; Hennessy et al., 2011).

\subsection{Sterol composition}

Sterols are very useful parameters for detecting adulterations or to check authenticity, since it can be considered as a fingerprint (Gharby et al., 2017, 2018). Besides, their determination is of major interest due to their antioxidant activity and impact on health. Table 3 lists the sterol levels obtained from Moroccan pomegranate seed oil.

The total sterol contents of pomegranate seed oil were $494.61 \mathrm{mg} / 100 \mathrm{~g}$, which was found to be in the range of previously published values for pomegranate seed oil from other countries reported in the literature $(408.9-620.5 \mathrm{mg} / 100 \mathrm{~g})$ (Kaufman and Wiesman, 2007). In pomegranate seed oil, $\beta$-sitosterol was also the most abundant sterol which constituted about $404.59 \mathrm{mg} / 100 \mathrm{~g}$. This sterol is also abundantly found in 
Table 4. Comparison of tocopherol composition (mg/100g) of "Sefri" Moroccan pomegranate seed oil with literature.

\begin{tabular}{lcccc}
\hline Compounds & Our results (mg/100g oil) & (Fernandes et al., 2015) & (Pande and Akoh, 2009) & (Jing et al., 2012) \\
\hline$\alpha$-Tocopherol & $74.62 \pm 1.77$ & $7.3-17.9$ & $161.2-173.7$ & $71.87-138.83$ \\
$\gamma$-Tocopherol & $190.47 \pm 3.52$ & $123.0-449.7$ & $80.2-92.8$ & $3.42-5.49$ \\
Plastochromanol 8 & $10.56 \pm 0.29$ & - & - & - \\
$\gamma$-Tocotrienol & $3.49 \pm 0.16$ & - & - & - \\
$\delta$-Tocopherol & $53.3 \pm 1.22$ & $4.9-15.2$ & $20.3-23.8$ & $141.42-351.32$ \\
\hline
\end{tabular}

Values are given as means of three replicates \pm SD.

Table 5. Comparison of oxidative stability (h) of "Sefri" Moroccan pomegranate with argan and olive seed oils.

\begin{tabular}{llll}
\hline Oil & Pomegranate & Argan (Matthäus and Brühl, 2015) & Olive (Mateos et al., 2006) \\
\hline Induction time (h) & $3.6 \pm 0.93$ & 6.1 & 5.5 \\
\hline
\end{tabular}

Values are given as means of three replicates $\pm \mathrm{SD}$.

sesame, cactus and olive oil (Gharby et al., 2012, 2017). Among the different sterols, $\beta$-sitosterol has been most intensively investigated with respect to its beneficial and physiological effects on human health. Besides, $\beta$-sitosterol lowers cholesterol levels, enhances immunity, and has anti-inflammatory, antipyretic and anti-carcinogenic effects (prostate essentially) (Gupta et al., 1980; Villaseñor et al., 2002). The next major component was campesterol where it reaches about $38.18 \mathrm{mg} /$ $100 \mathrm{~g}$ of the total sterols. $\Delta 5$-avenasterol and stigmasterol accounted for about 17.86 and $15.53 \mathrm{mg} / 100 \mathrm{~g}$ respectively in this oil. Minor sterols were also detected ( $\Delta 7$-stigmasterol and cholesterol). The sterol content of pomegranate seed oil from Morocco was similar to that from Georgia and Spain, as reported by Pande and Akoh, (2009) and Fernandes et al., (2015), respectively.

\subsection{Tocopherol composition}

In addition to the fatty acid composition and sterol profile, the composition of vitamin $\mathrm{E}$ active compounds is an important characteristic feature used to describe the identity of vegetable oils. These compounds have some nutritional importance because they are known to have an antioxidative activity, which protects the polyunsaturated fatty acids against oxidative deterioration; additionally, a biological activity exists, which protects cells against oxidative stress (Bieri and Evarts, 1974; Blumberg and Block, 1994; Tucker and Townsend, 2005).

The total tocopherol contents of pomegranate seed oil were $332.44 \mathrm{mg} / 100 \mathrm{~g}$, which is higher than that of argan $(85 \mathrm{mg} / 100 \mathrm{~g})$, olive $(22 \mathrm{mg} / 100 \mathrm{~g})$, sesame $(44.6 \mathrm{mg} / 100 \mathrm{~g})$ and cactus $(94.6 \mathrm{mg} / 100 \mathrm{~g})$ oils (Gharby et al., 2017). Only $\alpha$-, $\gamma$-, $\delta$-tocopherols, P8 and $\gamma$-tocotrienol were present in pomegranate seed oil (Tab. 4). $\gamma$-tocopherol was the main component and represented about $190.47 \mathrm{mg} / 100 \mathrm{~g}$ of total tocopherols, followed by $\alpha$-tocopherol $(74.62 \mathrm{mg} / 100 \mathrm{~g})$, $\delta$-tocopherol $(53.3 \mathrm{mg} / 100 \mathrm{~g})$, plastochromanol $8(10.56 \mathrm{mg} / 100 \mathrm{~g})$ and $\gamma$-tocotrienol $(3.49 \mathrm{mg} / 100 \mathrm{~g})$.

Our tocopherol profile was similar to the tocopherol composition reported by Fernandes et al., (2015), who revealed that the major tocopherol in pomegranate seed oil is $\gamma$-tocopherol $(123.0-449.7 \mathrm{mg} / 100 \mathrm{~g})$. However, this result contrasts with that reported by Pande and Akoh, (2009) study, where the $\alpha$-tocopherol was the major tocopherol in pomegranate seeds oil $(161.2-173.7 \mathrm{mg} / 100 \mathrm{~g})$. In addition, Jing et al., (2012) found that the main tocopherol in pomegranate seed oil is the $\delta$-tocopherol (141.42$351.32 \mathrm{mg} / 100 \mathrm{~g})$.

\subsection{Oxidative stability}

The preservation of edible or cosmetic oil is an important economic parameter (Matthäus et al., 2010). In fact, oxidation of lipid is a major cause of deterioration in the quality of oils. It is the cause of important deteriorative changes in their chemical, sensory and nutritional properties (Gray, 1978; Frankel, 1980). The oxidative stability of pomegranate seed oil is expressed as the induction period determined by the Rancimat method at $120^{\circ} \mathrm{C}$. The induction time of pomegranate seed oil, as evaluated by the Rancimat accelerated method, was found to be $3.6 \pm 0.93 \mathrm{~h}$ at $120^{\circ} \mathrm{C}$. At the same temperature, the Rancimat induction time is 6.1 and $5.5 \mathrm{~h}$ for argan and olive, respectively (Mateos et al., 2006; Matthäus and Brühl, 2015). Therefore, the oxidation sensitivity of pomegranate seed oil, that is much higher than that of argan and olive oils, could be likely attributed to high content of CLnAs; molecules that do oxidize easily (Tab. 5).

\section{Conclusion}

The study of pomegranate (Punica granatum L.) seed oil growing in Morocco revealed high oil content, with conjugated linolenic acids (punicic acid, catalpic acid) as the predominant fatty acid, beside considerable amounts of tocopherols and sterols. This study shows also that Moroccan pomegranate seed oil is particularly sentitive to oxidation, which could be explain by the high content of CLnAs. Thus, special care such as refrigeration should be considered for oil prolonged storage. If enough precautions are taken, pomegranate seed oil deserve 
to find its place in the cosmetics and food industry, as a potent functional and/or nutraceutical ingredient.

\section{References}

Ahlers NHE, Dennison AC, O’Neill LA. 1954. Spectroscopic examination of punicic acid. Nature 173(4413): 1045-1046.

Arao K, Wang YM, Inoue $\mathrm{N}$, et al. 2004a. Dietary effect of pomegranate seed oil rich in 9cis, 11trans, 13cis conjugated linolenic acid on lipid metabolism in obese, hyperlipidemic OLETF rats. Lipids Health Dis 3(1): 24.

Arao K, Yotsumoto H, Han SY, Nagao K, Yanagita T. 2004b. The 9 cis, 11 trans, 13 cis isomer of conjugated linolenic acid reduces apolipoprotein $\mathrm{B} 100$ secretion and triacylglycerol synthesis in HepG2 cells. Biosci Biotechnol Biochem 68(12): 2643-2645.

Aruna P, Venkataramanamma D, Singh AK, Singh RP. 2016. Health benefits of punicic acid: a review. Compr Rev Food Sci Food Saf 15(1): 16-27.

Bieri JG, Evarts RP. 1974. Gamma tocopherol: metabolism, biological activity and significance in human vitamin E nutrition. Am J Clin Nutr 27(9): 980-986.

Blumberg J, Block G. 1994. The alpha-tocopherol, beta-carotene cancer prevention study in Finland. Nutr Rev 52(7): 242-245.

Boussetta T, Raad H, Lettéron P, et al. 2009. Punicic Acid a Conjugated Linolenic Acid Inhibits TNFa-Induced Neutrophil Hyperactivation and Protects from Experimental Colon Inflammation in Rats. Plos one 4(7): e6458.

Elfalleh W, Ying M, Nasri N, Sheng-Hua H, Guasmi F, Ferchichi A. 2011. Fatty acids from Tunisian and Chinese pomegranate (Punica granatum L.) seeds. Int J Food Sci Nutr 62(3): 200-206.

Fadavi A, Barzegar M, Azizi MH. 2006. Determination of fatty acids and total lipid content in oil seed of 25 pomegranates varieties grown in Iran. J Food Compost Anal 19(6-7): 676-680.

Farmer EH, Van den Heuvel FA. 1936. Highly unsaturated compounds. Part VI. The triene acid from the seeds of pomegranates. J Chem Soc (Resumed): 1809-1811.

Fernandes L, Pereira JA, Lopéz-Cortés I, Salazar DM, Ramalhosa E, Casal S. 2015. Fatty acid, vitamin E and sterols composition of seed oils from nine different pomegranate (Punica granatum L.) cultivars grown in Spain. J Food Compost Anal 39: 13-22.

Frankel EN. 1980. Lipid oxidation. Lipid Res 19(1-2): 1-22.

Gharby S, Harhar H, El Monfalouti H, et al. 2012. Chemical and oxidative properties of olive and argan oils sold on the Moroccan market. A comparative study. Med J Nutrition Metab 5(1): 31-38.

Gharby S, Harhar H, Bouzoubaa W, Asdadi A, El Yadini A, Charrouf Z. 2017. Chemical characterization and oxidative stability of seeds and oil of sesame grown in Morocco. J Saudi Soc Agric Sci 16(2): 105-111.

Gharby S, Harhar H, Farssi M, Taleb AA, Guillaume D, Laknifli A. 2018. Influence of roasting olive fruit on the chemical composition and polycyclic aromatic hydrocarbon content of olive oil. OCL 25(3): A303.

Gray JI. 1978. Measurement of lipid oxidation: a review. J Am Oil Chem Soc 55(6): 539-546.

Gupta MB, Nath R, Srivastava N, Shanker K, Kishor K, Bhargava KP. 1980. Anti-inflammatory and antipyretic activities of $\beta$-sitosterol. Planta Med 39(6): 157-163.
Haddioui A. 2012. La culture du grenadier (Punica granatum L.) au Maroc. In: II International Symposium on the Pomegranate, CIHEAM/Universidad Miguel Hernández Zaragoza, pp. 79-81.

Hajib A, Harhar H, Gharby S, et al. 2018. Is geographic origin a good marker for cumin seed oil (Cuminum cyminum L.)? Riv Ital Sostanze Gr 95(3): 155-159.

Hennessy AA, Ross RP, Devery R, Stanton C. 2011. The health promoting properties of the conjugated isomers of $\alpha$-linolenic acid. Lipids 46(2): 105-119.

Hernandez FCA, Melgarejo P, Martínez JJ, Martínez R, Legua P. 2011. Fatty acid composition of seed oils from important Spanish pomegranate cultivars. Ital J Food Sci 23(2): 188.

ISO 659. 1998. Oilseeds - Determination of oil content (Reference method.

ISO 12228-1. 2014. Determination of individual and total sterols contents - Gas chromatographic method - Part 1: Animal and vegetable fats and oils.

ISO 12966-2. 2017. Animal and vegetable fats and oils - Gas chromatography of fatty acid methyl esters - Part 2: Preparation of methyl esters of fatty acids.

Jing PU, Ye T, Shi H, et al. 2012. Antioxidant properties and phytochemical composition of China-grown pomegranate seeds. Food Chem 132(3): 1457-1464.

Kahramanoglu I, Usanmaz S. 2016. Pomegranate production and marketing. CRC Press.

Kaufman M, Wiesman Z. 2007. Pomegranate oil analysis with emphasis on MALDI-TOF/MS triacylglycerol fingerprinting. J Agric Food Chem 55(25): 10405-10413.

Koba K, Imamura J, Akashoshi A, et al. 2007a. Genetically modified rapeseed oil containing cis-9, trans-11, cis-13-octadecatrienoic acid affects body fat mass and lipid metabolism in mice. J Agric Food Chem 55(9): 3741-3748.

Koba K, Belury MA, Sugano M. 2007b. Potential health benefits of conjugated trienoic acids. Lipid Technol 19(9): 200-203.

Ky`ralan M, Gölükcü M, Tokgöz H. 2009. Oil and conjugated linolenic acid contents of seeds from important pomegranate cultivars (Punica granatum L.) grown in Turkey. J Am Oil Chem Soc 86(10): 985-990.

Lansky EP, Newman RA. 2007. Punica granatum (pomegranate) and its potential for prevention and treatment of inflammation and cancer. J Ethnopharmacol 109(2): 177-206.

Mateos R, Uceda M, Aguilera MP, Escuderos ME, Maza GB. 2006. Relationship of Rancimat method values at varying temperatures for virgin olive oils. Eur Food Res Technol 223(2): 246-252.

Matthäus B, Brühl L. 2015. Quality parameters for the evaluation of coldpressed edible argan oil. J Verbrauch Lebensm 10(2): 143-154.

Matthäus B, Guillaume D, Gharby S, Haddad A, Harhar H, Charrouf Z. 2010. Effect of processing on the quality of edible argan oil. Food Chem 120(2): 426-432.

Melo ILP, Carvalho EBT, Mancini-Filho J. 2014. Pomegranate seed oil (Punica granatum L.): a source of punicic acid (conjugated $\alpha$-linolenic acid). J Human Nut Food Sci 2(1): 1-11

Pande G, Akoh CC. 2009. Antioxidant capacity and lipid characterization of six Georgia-grown pomegranate cultivars. J Agric Food Chem 57(20): 9427-9436.

Sassano G, Sanderson P, Franx J, Groot P, van Straalen J, BassaganyaRiera J. 2009. Analysis of pomegranate seed oil for the presence of jacaric acid. J Sci Food Agric 89(6): 1046-1052.

Syed DN, Afaq F, Mukhtar H. 2007. Pomegranate derived products for cancer chemoprevention. In: Seminars in cancer biology. Elsevier, pp. 377-385. 
Taoufik F, Zine S, El Hadek M, et al. 2015. Oil content and main constituents of cactus seed oils Opuntia Ficus Indica of different origin in Morocco. Med J Nutrition Metab 8(2): 85-92.

Toyama Y, Tsuchiya T. 1935. A new stereoisomer of eleostearic acid in pomegranate seed oil. J Soc Chem Ind Japan B 38: 182-185.

Tsuzuki T, Tokuyama Y, Igarashi M, Miyazawa T. 2004. Tumor growth suppression by $\alpha$-eleostearic acid, a linolenic acid isomer with a conjugated triene system, via lipid peroxidation. Carcinogenesis 25 (8): 1417-1425.
Tucker JM, Townsend DM. 2005. Alpha-tocopherol: roles in prevention and therapy of human disease. Biomed Pharmacother 59(7): 380-387.

Villaseñor IM, Angelada J, Canlas AP, Echegoyen D. 2002. Bioactivity studies on $\beta$-sitosterol and its glucoside. Phytother Res 16(5): 417-421.

Vroegrijk IO, Van Diepen JA, Van den Berg S, et al. 2011. Pomegranate seed oil, a rich source of punicic acid, prevents dietinduced obesity and insulin resistance in mice. Food Chem Toxicol 49(6): 1426-1430.

Cite this article as: Hajib A, Nounah I, Harhar H, Gharby S, Kartah B, Matthäus B, Bougrin K, Charrouf Z. 2021. Oil content, lipid profiling and oxidative stability of "Sefri" Moroccan pomegranate (Punica granatum L.) seed oil. OCL 28: 5. 